\title{
Food Processing: Policy for Rice and Oil Technology in South Asia
}

\author{
Barbara Harriss and Claire Kelly
}

\section{Rice Mills: the Experience of Modernisation}

The processing of rice was identified and taken up as a problem by the Government of India in an interactive relationship with expert agricultural consultants from the Ford Foundation. But it was not until four years after the appearance of the Ford Foundation's Report on the Food Crisis and Steps to Meet it [Government of India 1959] advocating the spatially (and socially) selective application of a technological package programme in agriculture, that the Intensive Agricultural District Programme consultancy was requested to advise the Government of India on ways and means of 'increasing practical outturn of edible rice' from paddy. Anticipating processing problems with gluts of marketed paddy they assessed the then surplus as of low quality (due to deficiencies in postharvest grain drying and storage practices) and the local huller mill technology as antiquated, high cost and unimprovable. Ignoring the little diffused under runner disc sheller technology, a comprehensive modernisation of the existing system along 'package lines' was advocated. It was envisaged that, between 1963 and 1970, a thousand three-tonne per hour (henceforth TPH) modern rice mills (henceforth MRMs) and a thousand 1-TPH rubber roll sheller mills should replace existing technologies at a total capital cost at 1963 prices of Rs 900 crores. Although research of modern mill technologies in India was at a very early stage at this time, modern equipment was available in Italy, West Germany, the United States, Japan and the Philippines |Faulkner, Reed and Brown (henceforth FRB 1963:26|.'

\footnotetext{
${ }^{1}$ Note on the rice technologies. The huller is a cast-iron or steel cylindrical roller revolving round a horizontal axis inside a sheath-casing. It can double-mill an average of 0.75 tonnes of paddy per hour. It was imported to India about 50 years ago and has been manufactured there for about as long. The 'antiquated' paddy-processing technology involves much more than milling. Paddy is dried on cement floors using the heat of the sun and the labour of women who skilfully turn the paddy at regular intervals in order to prevent it from becoming over-heated and cracking. In coastal India much of the paddy both marketed and consumed by producers is parboiled. This does not make the rice smell, as did traditional lengthy cold-soaking methods, and during the process the proteins, vitamins and oil are absorbed from the bran layer of the grain into the starchy endosperm. This renders the rice far more nutritious than if it is milled 'raw'.
}

The Government of India accepted these recommendations in principle and the fourth Five Year Plan specified 500 MRMs and 1,000 rubber roll shellers [Wimberly 1969:28].

Not only did the Government of India specify two technologies but it also created facilitative measures and institutions for it. Since the report estimated the capital cost of a 3-TPH MRM with adequate storage to be Rs 2 mn (assuming foreign collaboration in India over the manufacture of all but Rs 166,000 of the equipment) it must have been apparent that wìdespread adoption by the private sector was ruled out. It is therefore unsurprising that parastatal institutions were authorised as facilitative mechanisms for the modernisation of the processing industry: the National Co-operative Development Corporation (NCDC) and the Food Corporation of India (FCI).

It is the central government which has responsibility for the distribution of food, while state governments have responsibility for agriculture. The parastatals selected as vehicles for the implementing of technological change are central government institutions. The NCDC had originated in 1962 when the National Co-operative Development and Warehousing Board split up. This institutional fission resulted from internal conflicts of interest between participative aspects of co-operative development and the warehousing function. Warehousing was to draw on finance from the Reserve Bank of India both for (large scale) storage inf rastructure and, ultimately, to enable farmers to borrow from nationalised banks with stored crops as security. We shall see later that the financial requirements for large scale rice mill technology set up a similar contradiction within the National Cooperative Development Corporation. The Food Corporation of India was set up controversially in 1964 to 'provide a countervailing force to the speculative activity of the trader . . . to function generally as an autonmous organisation working on commercial lines' [GOI 1965:2]. Hence large scale processing technology

The technology introduced to replace the huller is the modern rice mill (MRM), a semi-automated factory consisting of mechanical handling and conveying equipment and oilfired driers, cleaners, bulk silo storage, mechanised parboiling equipment and a 2-4 tonne per hour (tph) mill of a rubber-roll type with paddy and by-product separators and polishers. 
was to be grafted onto a new mercantile parastatal of the central government. This institution was to coordinate both imports and the internal trade of basic wage goods. production of which was under the bureaucratic aegis of the states.

The NCDC was empowered to subsidise up to 100 per cent state co-operative investment in modern technology with loans at the subsidised interest rate of five per cent. while FCI financed mill construction directly. By contrast. the private sector. equated with the traditional technology. was to be discouraged from expanding further by restrictions on licensing. In 1970 the Rice Milling Industry (Regulation and Licensing) Amendment Rules prescribed that by 1973 the traditional huller be replaced by under-runner. emery disc shellers or by rubber roll shellers. that the use of the huller be confined to the polishing of rice and that licences of unsuitable mills be withdrawn [NCDC 1975:10-12].

However. at the same time as the innovations in milling were introduced. the Rice Milling Industry Act of 1958 continued to ban the establishment of any new rice mills except with a permit issued after ascertaining that the operation of a new mill would not displace labour from handpounding [Lele 1971a:236]! Let us not labour the point that both at the level of policy statement and at the level of authorisation these measures are contradictory. But handpounding is now rare and labour has been almost completely displaced by hullers. Whether or not the huller reduces drudgery of (female) labour or displaces it depends on the relations of production. Where household labour was used. diversion to the huller can be said to reduce drudgery. Where paid (wage or bonded) labour was used in pounding. this labour is displaced. Work in Bangladesh where the displacement of labour by the huller from handpounding and footpounding using the dekhi was less advanced than in India. demonstrated conclusively that maximum displacement (or drudgery reduction) was effected by this initial technological change compared with all subsequent ones |Harriss $1979 a$.

The case of a modern rice mill located in Northern Tamil Nadu illustrates further contradictions of institutionalisation. This mill. at Cheyyar in North Arcot District. was intended as a link in the expanded hierarchy of co-operative marketing societies throughout the state which would compete in free market trade in agricultural commodities and deal in the supply of inputs. In the event. the 13 co-operative marketing societies with responsibility for MRMs in Tamil Nadu relinquished control of them in 1972 to the newly formed Civil Supplies Corporation. This state-level parastatal trading corporation emerged out of conflicts over the control of surplus rice between central and state governments (a conflict and a bureaucratic outcome generalised through many states in India). In the case of Tamil Nadu this conflict was exacerbated by the differences between political parties in power at state and central levels. The Civil Supplies Corporation's role is to purchase and mill publicly procured paddy. Cheyyar Taluk Marketing Society is the only co-operative in North Arcot District which markets paddy. but its trade is insignificant -56 tonnes in 1972/73. none of which was in fact milled at the MRM but was sold as paddy to other co-operatives in Tamil Nadu [Director. Tamil Nadu Civil Supplies Corporation. Personal Communication. February 1973].

So from 1970-74 the institutional system within which this MRM functioned changed considerably. Firstly. free market operation was replaced by operation within the fixed price margins of the levy system. Secondly. local supply was replaced by supply comprising the levied marketed surplus of the entire district. Thirdly. had the co-operatives expanded their paddy marketing operations. the storage infrastructure from which the mill was supplied would have been larger in total capacity and more decentralised than the present 600 tonnes on the site. The decision to innovate was thus taken as a technical one. in bureaucratic isolation from. or ignorance of. the institutions through which control over the operation of the technology was to be exercised.

The resources allocated to upgrading the technology of rice milling have been far less than those planned. Out of the target of 2.000 MRMs planned to be in existence by 1969. NCDC and FCI had financed (or contributed investment capital to) 33. a third from Germany. and the rest from Japan [Wimberly 1969]. Seventeen of these are in Tamil Nadu alone: four built by $\mathrm{FCI}$ in the Kaveri Delta. and 13 by NCDC throughout the state.

Meanwhile. in spite of the ban on the huller. the latter had increased in number from an estimated 8.000 10.000 in 1963 to 83.600 registered and licensed in 1974 |NCDC 1975:6|. Of the All India total of rice mills, the co-operative sector owned 700 . less than one per cent. and the abundant majority of these were huller mills.

Table 1 summarises the results of studies of the operational economics of huller mills and the modern rice mill in North Arcot district of Tamil Nadu. Levels of capacity utilisation are higher. total costs lower. female employment far greater and the consumption of non-human energy far lower in the huller sector than in the modern rice mill |Harriss 1977|. A detailed analysis of social cost effectiveness. taking externalities into account and simulating a standardised institutional 
environment confirmed the greater appropriateness of sets of hullers than the MRM package [Harriss $1979 \mathrm{~b}$. Further public investment in this package has now been halted and the original plans scrapped. The sixth Five Year Plan concerns itself only with public policy for technology for the modernisation of postharvest technology for onions and potatoes [GOI 1981:111].

The modern rice mills still remain subsidised by the state. Meanwhile the growth of large surpluses of rice in a few regions of India (Punjab, the Krishna and Godaveri Deltas, Thanjavur district) has provoked private millers into adopting appropriate components of the modern rice mill package (eg rubber roll shellers and cone polishers).

\section{The Decision to Innovate}

In order to explain the committing of public resources to inappropriate large scale packages of technology we have to look in detail at the rationale behind the original recommendations to the Indian Government. The brief was to find ways other than by increasing paddy production by which to increase the final output of rice. The report was highly critical of storage technology, of pre-milling processing, of mill technology, the quality of rice and the quality of management. Much of the argument was concerned with the impact of technology on food supply and nutrition. We will consider the basis of each section of their argument.

\section{a) Storage}

Recommendations for storage were based on assertions about the nutritional impact of quantitative and qualitative losses in existing storage. It was recommended that 'Farmers should be encouraged to dispose of their marketable (sic) surplus immediately after harvest so that paddy could be scientifically stored rather than stored in village and mandi insect and rodent filled go-downs' [FRB 1963:10] . . 'over 90 per cent of the paddy observed in storage facilities in farmers' compounds, co-operative go-downs and millers' go-downs had been damaged by insects, rodents, birds and moisture' and 'loss in storage is 10 per cent of marketable surplus'. In the light of later studies, [ eg Greeley 1978] this is high. These statistics were apparently estimates made in 100 rice mills (five in each of 20 Indian districts) and presumed the ignorance of the magnitude of losses or of ways to prevent them on the part of farmers and millers, or apparently such a crude monopoly control of prices by those who stored that losses were of no consequence. These assumptions had and have little basis in fact.

table 1

Summary of factor utilisation by two operational rice milling technologies in North Arcot district, Tamil Nadu, 1973-74

\begin{tabular}{|c|c|c|c|}
\hline factor & efficiency criterion & $M R M$ & $\begin{array}{l}\text { av. traditional } \\
\text { huller }\end{array}$ \\
\hline capital & $\begin{array}{l}\text { capital costs } \\
\text { fixed costs per tonne } 1972-73 \\
\text { variable costs, boiling and hulling } \\
\text { engineering capacity utilisation } \\
\text { effective capacity utilisation }\end{array}$ & $\begin{array}{l}\text { Rs } 1,190,928 \\
\text { Rs } 50.29 \\
\text { Rs } 28.36 \\
25 \text { per cent } \\
28 \text { per cent }\end{array}$ & $\begin{array}{l}\text { Rs } 30,000 \\
\text { Rs } 11.14 \\
\text { Rs } 31.73 \\
14 \text { per cent } \\
40 \text { per cent }\end{array}$ \\
\hline labour & $\begin{array}{l}\text { 'managerial' (salaried: MRM) } \\
\text { salaried } \\
\text { coolies } \\
\text { turnover per manager } \\
\text { per employee } \\
\text { per coolie }\end{array}$ & $\begin{array}{l}8 \\
27 \\
25 \\
418 \text { tonnes } \\
124 \\
134\end{array}$ & $\begin{array}{l}1.4 \\
3 \\
10 \\
400 \text { tonnes } \\
180 \\
42\end{array}$ \\
\hline land & $\begin{array}{l}\text { area required to supply mill at effective capacity: } \\
\text { Samba } \\
\text { Navarai } \\
\text { Sornavari }\end{array}$ & $\begin{array}{r}9,756 \text { hectares } \\
15,152 \text { hectares } \\
32,000 \text { hectares }\end{array}$ & $\begin{array}{l}397 \text { hectares } \\
830 \text { hectares } \\
1,660 \text { hectares }\end{array}$ \\
\hline \multicolumn{2}{|c|}{ consumption of non-animal/non-human energy per tonne milled } & Rs 18.89 & Rs 6.9 \\
\hline
\end{tabular}


The technology proposed, the reinforced concrete bulk silo, minimum size 200 tonnes, had the advantage of being large, necessitating centralisation of marketed surplus at the mill immediately post-harvest (though the pricing policies to encourage farmers to yield up surplus promptly--monopoly procurement at high and fixed prices - were not elaborated) and it was said to give 'full protection against all losses' [FRB 1963:22]. These silos represented 66 per cent of the capital costs of the factory technology proposed. Until the work of Desai [ 1969:46] and Gupta and his team [1970:102] no evaluation of silos were available for India.

Desai obtained a benefit cost ratio at market prices of 0.74 which did not justify construction. Gupta found that silos were only profitable (let alone cheaper than alternatives) if used permanently at 75 per cent of capacity or more. This is operationally infeasible. If adequate data for a table of capital costs were available in 1963 it is strange that its diseconomies at low capacity were not internationally known. Practical operational problems with silos have included their lack of versatility, the fermentation of paddy, the monitoring of quantities and condition of mixed lots of paddy inside the silo, their fumigation and their interior repair and maintenance, necessitating the biannual construction of interior scaffolding [NCDC 1975:71-5]. The costs of resolving such problems were not foreseen.

Other technical discussion concerned factors which also bear on nutrition. Several issues were brought up: the 'nutritional wastage' resulting from losses in raw milling; that resulting from milling paddy in a raw state rather than after parboiling, and that resulting from quality deterioration due to poor pre- and post-milling treatment (parboiling and polishing respectively). We shall examine these issues.

\section{b) Pre-milling processing}

The report deplored the nutritional waste in raw milling and pointed out that parboiled rice yields three to five per cent more edible rice, because the gelatinisation of starch hardens the grain. It is consequently more resistant to the steel screens of the huller or to the rubber rollers of the new mill, therefore yielding up fewer brokens [NCDC 1975:1011]. Table 2 indeed establishes the nutritional superiority of parboiled rice.

The report's recommendations did not include measures to facilitate the adoption of parboiling units by traditional millers but instead advocated a technology involving at a minimum six parboiling vats with electronic temperature controls and steel work bins powered by an $80 \mathrm{HP}$ oil-fired boiler together with a six-ton oil-fired mechanical drier, the whole connected by mechanical conveyor belts and bucket elevators. Paddy is soaked in water at $65-70^{\circ} \mathrm{C}$ or in saturated steam for two to three hours which prevents the growth of bad-smelling bacteria, a disadvantage of traditional one to three days' cold soaking methods. Having absorbed moisture to 35 per cent of its weight, paddy is mechanically dried eliminating use of the sun criticised by FRB as 'only possible for six to eight hours a day for 200 to 240 days of the year' and the depredations of birds on the traditional drying floor, which FRB estimated could reduce marketed surplus by up to three per cent. These units represent ten per cent of total capital costs. In spite of the fact that 'the economics of parboiling are obvious' [Desai 1969:44] no study to the writer's knowledge establishes the economic superiority of the advanced technology of parboiling.

table 2

Vitamin and protein content of raw and parboiled rice

\begin{tabular}{lccl}
\hline B-vitamins $\quad \mathrm{g} / \mathrm{gm}$ & $\begin{array}{l}\text { brown rice } \\
\text { (rice with bran) }\end{array}$ & raw rice & $\begin{array}{l}\text { parboiled } \\
\text { rice }\end{array}$ \\
\cline { 2 - 4 } thiamine & 4.2 & 0.8 & 2.57 \\
niacin & 47.2 & 18.1 & 39.8 \\
pyridoxin & 10.3 & 9.5 & - \\
pantothenic acid & 17.0 & 6.4 & - \\
riboflavin & 0.53 & 0.26 & 0.36 \\
protein \% & 8.3 & 7.6 & 7.8 \\
\hline
\end{tabular}

Source: Parpia and Desikachar in IIM 1969:84.

Desai [1969:44-8] uses the capital budgeting technique to appraise an investment of Rs 259,000 in two driers sufficient to dry paddy to feed a 4-TPH MRM at 100 per cent capacity utilisation for a project life of 10 years. At current market prices he found a benefit cost ratio of 2.7 , which shows it to be profitable, though not necessarily allocatively efficient since the alternative-sun-drying - was not assessed. Moreover, both the parboiling units and the modern driers also use fuel oil whose price has quadrupled since October 1973. Research in India has now resulted in a huskfired box furnace for both driers and parboiling units. But husk boilers are not efficient heat exchangers and husk, being of low density, will require large stores and will have high transport cost components in areas where driers (which can be located independently) are not juxtaposed to mills. 
The paddy driers require skilled operators. The calculation of drying time needed in this machine 'varies with drier type and size, variety of paddy, bed depth, prevailing humidity, quantity of air, velocity through drier, tempering and storage space and capacity of the conveying equipment . . .; ' . . the drier operator has to have data on drying air temperature, velocity of air through the grain, humidity of the drying air, number of passes of the paddy, minimum time for tempering and the time of harvest' [Desai 1969:45].

The point of these technicalities is not so much their complexity but the likelihood that the operator will revert in time to using the same 'experience' necessary in using the free heat of the sun. Although sunshine is a free good, sun-drying requires investment in a drying floor and in the variable costs of supervisory labour and in maintenance. Comparative economic analyses of the sun and of mechanical drying have still not apparently been done in India. If the sun were to prove a less costly means of drying, further analysis of rainfall records and the trends of harvest timings for individual locations would show whether or not mechanical driers were justified for a few weeks of the year. Full sunlight is not necessary for sun-drying. Farmers in Sri Lanka and Bengal can and do shade dry in cloudy and relatively humid weather down to a moisture content of 11 per cent. Similarly, the Mysore hot soak method does not require large scale highly capitalised equipment and has been adapted by the private sector to the small, husk-fired tanks, kettles and drums of the traditional mills. Indeed, in North Arcot district this locally modified innovation is already widely difused, and 50 per cent of the marketed surplus and most of subsistence production is processed with this technological adaptation.

\section{c) Milling outturns}

It was stated that outturn from traditional rice mills averaged between 55 per cent and 60 per cent of raw rice by weight from paddy, of which $20-50$ per cent were brokens. Outturns of parboiled rice were between 58-65 per cent by weight [FRB 1963:12-13]. In the report the modern mill by itself is said to achieve 64 per cent outturn, the mills with 1,000 tons of silo storage, 66 per cent, with mechanical threshing and mechanical driers on farms, 68-72 per cent and with 6,000 tons of silo, 68-74 per cent. It is stated that the value of rice saved from the modern mill package 'would pay for its cost in one year' and would 'save five times more than its foreign exchange cost in one year' [FRB 1963:19]. In the progress report on the MRM programme in 1969 the outturns specified were huller 64 per cent, rubber roll sheller 68 per cent, and MRM potentially 72 percent [ Wimberly 1969:3]. Since outturn differentials are crucial to the costings proposed, it is important to consider their basis. Outturns were 'either weighed or carefully estimated . . in a few cases moisture tests of rice have been made ... estimates have been made of dirt and admixtures in both the paddy and the rice... Percentage of broken rice in head rice has been estimated by observation' [FRB 1963:6-7, 13, author's emphasis|. These quotes speak for themselves. Then it is reasonable to assume that milling outturn is a function of paddy variety though little actual evidence is published on this. One test on the huller in 1961 showed a five per cent difference in outturn due to variety in raw rice [Sriraman et al 1963:450].

It is not realistic to base economic appraisals on the contrasts in outturn between those achieved by MRM in Japan or the US when milling homogeneous paddy and those achieved by Indian millers milling heterogeneous consignments. Local conditions could be simulated at appraisal stage, achieved by milling ordinary Indian paddy in an existing MRM. This was apparently done, but the results were suppressed at the time.

All subsequent operational analysis show no statistically significant difference between the technologies [Harriss 1976). Further, the assumptions that a desirable goal is to minimise the outturns of brokens and that rice or brokens which get mixed with by-products are lost to society in traditional technologies [FRB 1963:12] may misinterpret aspects of the social culture of rice in India.

Lele [1970:6] draws attention to the fact that Indian society demands brokens for certain culinary preparations. Many rice retailers in Tamil Nadu sell brokens at three quarters the price of head rice. There is a high demand for brokens from the poorer sections of society who may be denied rice or millets by local scarcities or high prices and who will not have sufficient purchasing power for rice in the foreseeable future. The assumption that all rice which finishes up with the by-products is being wasted is wrong. Most millers in South India sieve the by-products either mechanically or by hand. Payment to coolies for mill work is often partially given as brokens or sieved rice. To assume international rather than local standards in project appraisals is to reduce the local social value of such procedures.

\section{d) Rice quality}

The FRB report criticised the quality of rice because of its adulteration with admixtures and 'the offensive odour and undesirable flavour particularly for many classes of consumers' of traditionally parboiled rice [FRB 1963:10-11]. The first criticism relates to the condition of paddy sold for milling, not to mill technology. It has been seen that local adaptations of the hot soak technology have improved the flavour 


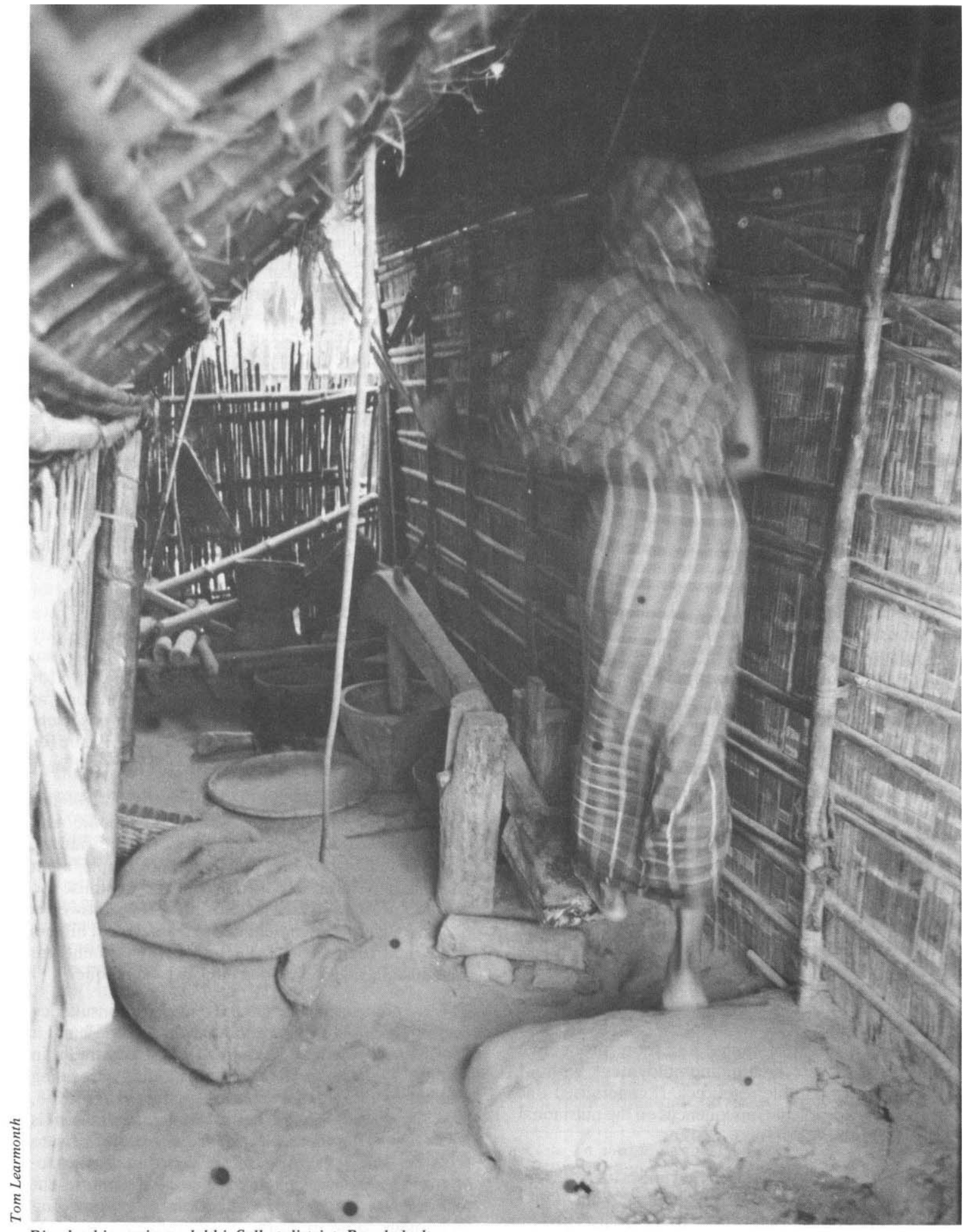

Rice husking using a dekhi, Sylhet district, Bangladesh. 
though not altered the economic inferiority of parboiled rice.

The progress report observed that rice produced from the MRM is so superior to that from other technologies that governments hinder the process of modernisation when they fail to provide premium prices for it |Wimberly 1969|. One reason why incentive prices are generally not paid is that output with a four per cent polish is economically inferior to more highly polished grain. may even be rejected as inedible and is unacceptable on the international market. The Thai rice exported on the world market and 'coveted by the discriminating is milled in traditional huller rice mills |de Padua 1974:117|. Lele points out that the perception of quality is a culturally conditioned matter and she suggests that concern in the early 1960 s about poor domestic quality may have been based on the high and domestically irrelevant standards of international trade [1970:6].

Thus, nutritional factors were used to support the technological ones in the original report. Both sets of factors consisted of assertions based on little local evidence rather than on the measured results of experimentation. Furthermore there are other nutritional consequences of such technological change which played no part in the original decision on resource allocation.

\section{e) Livelihoods and employment}

Technological change may require more capital and less labour, or less capital and less labour, or less capital and more labour per unit of output. A choice at any time may depend on relative factor prices but it is often the case that new large-scale technologies are more productive both per unit of capital and per unit of labour than are older small scale ones. In such cases governments in the common situation of having multiple national objectives take allocatively suboptimal decisions when favouring livelihood intensive projects. Given the Indian Government's commitment to 'job creation' [GOI 1981], it is important to see whether such a conflict arises in this case. For the generalised adoption of technologies which are more productive per unit of capital and labour creates unemployment while also creating resources potentially redistributable to the unemployed. Technologies which are less productive per unit of capital and more productive per unit of labour create unemployment without creating redistributable resources. If generalised this has obvious malevolent consequences on the nutritional status of those in the labour market.

We have seen that the modern rice mill is less efficient per unit of capital than is the huller. What about labour? Traditional hullers in S. India are manned by an owner (plus his family or two partners) and from one to six 'technicians' who supervise the machinery and the parboiling and drying of paddy. The average huller with a turnover of 610 tonnes per annum has a gang of about ten casual coolies, mainly women, who turn the paddy as it sun-dries and who sieve the residue from milling and separate the by-products. Carrying work is done by male coolies according to the availability of work. The MRM has an administrative complement of eight doing the work performed by the traditional huller owner. Its engineering and technical section, comparable with the salaried employees of a traditional mill, numbers 19, eight of whom are of higher formal technical calibre than found in the traditional sector. The stores give work to five people, and about 25 male coolies are hired for carrying and loading. No unskilled labour is used for the traditionally intensive boiling and drying processes.

If we assume fixed coefficients for labour and no economies of scale in the numbers of livelihoods created in the two sectors with increasing capacity utilisation, the production of 8,160 tonnes of rice per annum will create livelihoods in the huller sector for 30 managers, 60 salaried employees and 302 (female) coolies. In the MRM sector it will create jobs for 28 administrators and qualified engineers, 68 technicallytrained employees and 90 (male) coolies. This suggests that Timmer's conclusion from an analysis of employment in the rice marketing sector of Java [1974] supported by Simmons [1975] and Ngoddy [1976] for rural food processing industries in Nigeria, namely, that small gains in technical efficiency (for example in outturn of head rice) may be made only at the expense of the most vulnerable segments of society who can least afford to forego employment, is true for conditions in India.

However, 'skilled' labour is said to have a higher propensity to save than has unskilled labour. And savings contribute to the growth of future output. Does the huller technology in maximising employment also maximise present consumption and minimise the generation of reinvestible resources? The answer is no. As long as we assume that the managers of hullers are skilled then savings per unit of investment are maximised using the labour intensive technique.

This is a controversial assumption and the consultancy establishment is divided about it. On the one hand it has been stated that no managers of rice mills in Andhra Pradesh were 'qualified in rice processing technology or in management' | Gupta et al 1970:37-8, 105]. On the other hand 'better management talent is necessary to compete with the experience of private millers' [Wimberley 1969:27]. Even though the cooperative sector was planned by central government to implement the modernisation of processing technology, only six of the co-operative sector's 700 mill managers had sufficient formal educational 
qualifications to attend courses in mill management financed by the US at Kharagpur [NCDC 1975:75-80] and these men left the co-operative department for private sector employment after this course.

\section{f) Engineering problems}

Finally we note a number of engineering problems connected with the modern package that have led to its failure as an instrument of modernisation.

i) The bulk silos are technically difficult to fumigate, monitor temperature in and maintain. Further, their lack of aeration is technically appropriate for cool, dry, temperate climates but not for hot and seasonally humid tropical ones [NCDC 1975:71-5; de Padua 1974:115] which affects the moisture content of paddy, the degradation of chlorophyll and aminoacids and the flourishing of bacilli and mycotoxins. De Padua, in asking nine at present unanswered questions reveals an inadequacy of adaptive research in storage technology within Asia which still persists.

ii) Precleaners of paddy for the grading and standardising of mixed batches prior to milling have been found essential. These machines were not planned and special subsidies had to be granted later for them. Often in India the precleaners fitted are of lower capacity than the mill machines and have accordingly reduced potential throughput and raised the fixed cost component.

NCDC, in evaluating co-operative MRMs, have encountered other engineering problems.

iii) Batch Driers: in contrast to the precleaners many batch driers are of too great a capacity to dry homogeneous consignments of grain [1975:67]. De Padua also notes 'theoretically the air volume at the pressures needed requires only about 1-HP, yet because of inefficiences' (on the reasons for which he is silent) 'a 5-HP engine has to be used. Frequently because of poor blower performance the moisture gradient between top and bottom is too high, necessitating manual mixing of the batch' [1974:115].

iv) Husk: the Union Department of Food is now ruling that all MRMs have parboiling units and that all new units should be husk rather than oil or coalfired (NCDC 1975:70). Considerable research has already been done to adapt boilers to husk [Subrahmanyam 1975:95-107|, but the availability of husk is now a constraint in complexes with huskfired driers and parboiling units since husk is a low grade fuel, and its current low value and high bulk constrain long distance trade. v) The rubber rollers of the mill should be parallel when installed, reversed frequently and removed if uneven. They require frequent ventilation, and unadulterated paddy to operate at specified levels. Whereas German rubber rollers mill 300 tonnes of paddy, Japanese ones mill 250 tonnes, Indian manufacturers specify 150 tonnes but the cooperative sector has found Indian rubber of poor quality, wearing out after 60-70 tonnes /NCDC 1975:681.

vi) Finally, de Padua notes a range of engineering problems connected with clogging on and abrasion of conveyor belts, elevator buckets and screw augers, stemming from the greater moisture and higher silica content in the husk of south and south eastern Asian paddy compared with Japanese varieties [1974:116].

Publication of these engineering imperfections by local experts has lagged behind specification of the MRM package by about ten years, a lag which has enabled the further diffusion to parastatal institutions in south and south east Asia, with results known to be similar to this case in Malaysia and Sri Lanka /de Padua 1974:116; G. Elliston, University of Malaysia, Personal Communication, 1976]. ${ }^{2}$

Hence we have found that the isolation of a decision to allocate public resources for a specified technological package from decisions on ramifying policies and institutions led to the adoption of a technology inappropriate to the factor endowment, and untested to the ecological environment.

\section{Edible Oil: the Experience of Modernisation}

Groundnut crushing in India is characterised by competition between five technologies (each varying in capacity and in type and size of motive power) all producing a similar end product. As with rice milling, technological change has been occurring over a long period. Now all five technologies may operate within one district (eg Coimbatore in Tamil Nadu): the bullock driven chekku or ghani-a wooden pestle and mortar; its motor driven 'intermediate' upgraded version; the metal rotary which began to diffuse in the 1940 s; and the higher capacity expellers introduced in the 1950s. These may all operate in tandem with decorticators of various capacities which remove the outer pod. Lastly the solvent extraction plant extracts oil from groundnut oil cake. While there were two

${ }^{2}$ Note on the discussion of modernisation. We have not treated the entire debate in this article, only those aspects with a bearing on nutrition. Topics such as capacity utilisation, use and treatment of by-products are examined fully in Harriss [1976]. 
such plants in India in 1950, there were about 200 in existence by 1976 [Achaya 1979]. ${ }^{3}$

Table 3 summarises the economic characteristics of three of these oil milling technologies. In terms of labour, one expeller displaces 55 chekkus and 314 work places. But chekkus are a 'model' appropriate village technology. Locationally dispersed, they suit the local factor endowments with negligible overhead costs, locally repairable and replaceable equipment, no use of non renewable energy and high labour intensity. However, on cost of production criteria they are far less efficient than are rotary and expeller mills [Kelly 1981, ch 2].

Public policy towards oil processing technologies has embodied similar contradictions as has that for rice milling. On the one hand the village oil industry is protected. On the other, public resources have been allocated to very large oil mill complexes and to

${ }^{3}$ Note on oil milling technologies. The village chek $k u$ or ghani consists usually of a wooden pestle and mortar, the pestle connected to a shaft, to which one or two bullocks are yoked. Each part of this equipment is locally available and replaceable. The bullocks circumambulate, crushing the oilseeds in the mortar by the rotation of the pestle. The oll, scooped out or extracted by soaking a cloth, is not filtered and the percentage of extraction in chekkus varies from 33-40 per cent.

There is a powered version of the chekku or power ghani mounted on a metal shaft and bearings and driven by a $2-\mathrm{HP}$ electric motor. Here the oil flows from a hole in the mortar into a container.

Rotary mills are based on a similar design but are electrically or diesel powered and in some cases both mortars and (threaded) pestles may revolve. They are often used in series and mills containing several hundred have been reported. The seeds or cake or kernels may be heated to increase the percentage of oil extracted, the average of which is 37 per cent.

Expellers have been domestically manufactured since the 1950 s. Each consists of a steel cage containing a revolving shaft with a series of hundreds of steel worms arranged along it in such a way that increasing pressure is exerted on the seeds as they move from one end to the other. Oil drains out through perforations and the cake is forced out of the end. The cake is usually broken up, heated, and passed through the expeller again. The oil is filtered. The extraction percentage is higher because of the double pressing process and may reach 42.5 per cent.

Solvent extraction plants extract oil from oilcake or rice bran (though the latter must not be rancid). A chemical solvent (usuaily hexane) percolates through the material. The solvent mix is distilled and condensed. The solvent is re-usable and the oil is treated to remove traces of the solvent. The process extracts almost all the oil remaining in the oilcake (13-14 per cent from chekku oilcake and 8-9 per cent from mill oilcake) and it all takes place in a single tank or battery system. solvent extraction plants (no data on whose operational economics are readily available).

\section{a) Protection of the village oil industry}

Commitment to the protection and promotion of rural employment is enshrined in the Constitution and has been reiterated in all Five Year Plans. The first talked of:

- reservation of spheres of production to village industry;

- non-expansion of the capacity of large scale industries;

-imposition of taxes on large scale industries;

- arrangement for raw material supplies to village industries;

-appropriate research and establishment of training programmes [GOI 1950:322].

Between the first and the sixth plans there were shifts in statements towards the organisation of co-operatives and towards the upgrading of existing technologies and their conversion to electric power. Table 4 shows a decline in the allocation of public resources to the small scale industry.

These paper statements have failed to halt a decline in the absolute number and relative importance of the small scale technology. From 1921 to 1951 the estimated decline in employment was from 500,000 to 200,000 [Rao 1979]. The conclusions of the 1950 report of the Committee for the Protection of the Village Oil Industry in Bombay Province cites reasons for its decline which are quite relevant to contemporary relations of production and exchange. These include high costs of production, undercapitalisation and lack of finance, lack of uptake or adoption of improved small scale technologies, weak and undependable motive power (fickle electricity supplies, high fodder costs for bullocks). The report of the All India Oil Seed Crushing Inquiry of 1955 sought to protect the village industry by preventing the installation of new oil mills on the one hand and by supplying oilmen with subsidised improved ghanis, subsidies on freight and credit, and excemptions from excise duties and tax on the other. Only the latter has been implemented.

In 1980 protection ran to offers of government loans of Rs 6-7000 for power ghani conversions. However, since security was Rs 15,000 few oilmen could take advantage of this credit facility. Similarly official exemption from sales taxes represents no price advantage to chekku or ghani products in the market in view of widespread evasion of such taxes by owners of taxable businesses. Sales tax exemption for small scale technologies is subject to restrictions on turnover which prevents speculative trading in bulk or over periods greater than one week and therefore severely inhibits the accumulation of an investible surplus. 
table 3

Summary of cost and operational structures of three oil milling technologies in Coimbatore district, Tamil Nadu, 1979-80

\begin{tabular}{|c|c|c|c|c|}
\hline & chekku & rotary & expeller & $\begin{array}{l}\text { oil mill complex and } \\
\text { solvent extraction plant }\end{array}$ \\
\hline ratio of turnover & 1 & 4.5 & 55 & \\
\hline investment per unit (Rs '000) & $2.5-5$ & $89-176$ & $242-300$ & $6675-12960$ \\
\hline ratio of average processing costs & 3.0 & 1.9 & 1.0 & nd \\
\hline engineering capacity utilisation & about 80 & 35 & 47 & nd \\
\hline labour costs as $\%$ total annual costs & 27 & 33 & 19 & nd \\
\hline ratio of average labour productivity & 1.0 & 2.0 & 9.8 & nd \\
\hline $\begin{array}{l}\text { non-renewable energy costs Rs/tonne } \\
\text { of kernel milled }\end{array}$ & nil & 64.0 & 37.5 & nd \\
\hline
\end{tabular}

Source: Kelly $1981: 18-27,64$.

nd $=$ no data

table 4

Government of India planwise disbursement for the ghani oil industry

\begin{tabular}{lrrr}
\hline & grant & $\begin{array}{l}\text { loan } \\
\text { Rs lakhs }\end{array}$ & total \\
\hline & & & 31.00 \\
First Plan (1953/54-1955/56) & 11.53 & 19.47 & 532.49 \\
Second Plan (1956/57-1960/61) & 157.51 & 374.98 & 815.81 \\
Third Plan (1961/62-1965/66) & 165.65 & 650.16 & 626.19 \\
Fourth Plan (1969/70-1973/74) & 31.90 & 594.29 & 546.24 \\
Fifth Plan (1974/75-1977/78) & 28.77 & 517.47 & 197.60 \\
Sixth Plan (1st year 1978/79) & 11.53 & 186.07 & \\
\hline
\end{tabular}

Source: Panditrao 1980

\section{b) Promoting modern technology}

The second initiative that has been taken towards the oil processing industry is in the form of state investment in very large oilseed processing plants. These fall into two main categories: basic solvent extraction plants, and integrated processing units consisting of a combination of oil milling and solvent extraction facilities, usually linked with a refinery and a vanaspati unit, or other industrial sidelines. Solvent extraction plants operate either on rice bran or oilcake, the latter having capacities of between 15 and 100 tonnes of groundnut cake per day.
Very little information is published by these parastatals on initial investment costs, except in a highly aggregated form, but for 1977 block costs of between 6.6 and 13 million rupees for single units were estimated [NCDC 1976:531.

As with modern rice mills, this level of investment is beyond the means of most of the private sector, hence modern technology is financed and controlled by parastatal institutions such as state Agro Industries Corporations. The most important of these institutions is the National Co-operative Development Corporation 
(NCDC). A survey on the extent of the co-operative character of these oilseed units in 1980 produced the following summing up by Professor K. K. Taimni: their values have been purely commercial, their concerns limited to their survival and their commitments to basic philosophy to co-operative ideals of membership participation and mutuality of interest, merely on paper, if at all' [NCDC 1980:70].

The only data on employment, derived from the Annual Survey of Industries [Jalan 1979] suggested that in 1974-75 there were 55 edible oil and fat factories in the 'large scale sector' employing a total of 7242 people such that average employment per unit is 132 . There is no justification for state investment in such mills on grounds of employment generation.

As with modern rice mills, the utilisation of capacity in modern oil mill complexes has been low, averaging 35 per cent of engineering capacity [NCDC 1980:73-9]. Reasons, analysed in detail by Kelly [1981:48-55], include inappropriate sites and locations, difficulties in 'co-operative' decision-making while operating in volatile markets for oil and for by-products, shortages of raw materials, electricity and transport. These constraints on capacity utilisation are identical with those for modern rice mills [Harriss 1977]. Hence the promotion of modern technology is as ineffective as is the protection of the small scale technology.

\section{The Decision to Innovate}

As with rice, part of the argument used by the NCDC turns around the benefits to oil supply in reducing wastage and improving quality.

\section{Oil outturn}

'The private sector mills mostly constituted village ghanis. The expeller units were also not very efficient and the machinery installed was mostly out of date resulting in a lot of wastage of oil during crushing. It was, therefore, advantageous to install modern continuous plants' [NCDC 1975].

The implication that both ghanis and expellers are 'not very efficient' is presumably a reference to their lower percentage outturn of oil from seed than that achieved by 'updated' expellers and solvent extraction plants. However, the installation of solvent extraction plants in order to extract the remaining 13-14 per cent of oil from groundnut oilcake, should replace the need for state investment in primary crushing units at all. The implication moreover that the replacement of private sector crushing capacity with state subsidised co-operative crushing capacity will improve the record of 'wastage' seems inaccurate. Chekku telis lose no part of their product, and it is debatable as to whether that oil left in the cake can really be termed 'waste'. ${ }^{4}$ At the same time, one of the operational problems is the loss of material in transit and in processing, eg an NCDC assisted rice bran solvent extraction plant in Orissa state showing a total handling and process wastage of around 6-7 per cent [NCDC 1980:85].

\section{Benefits of co-operation}

The NCDC has also justified investment in high technology in terms of killing two birds with one stone; replacing exploitive middlemen and encouraging co-operation in marketing among oilseeds producers [NCDC 1980:73]. The same document, however, declares there is hardly any mill which is making purchases of raw materials directly from the growers'.

They have also been justified because the private sector has no investible surplus for technologies on this scale and size. As Kelly comments, the only conceivable real reason for resource allocations which, like many of the modern rice mills, require continual subsidies 'would be in anticipation of an unprecedently rapid rise in oilseed production' [1981:55]. India's production of edible oil in which she used to be an exporter has failed so far to match the rise in effective domestic demand.

In this context it is interesting to note the association between the NCDC and the Co-operative League of the USA. This league has recommended the encouragement and improvement of co-operatives by a programme aimed 'to transmit the experience of the US oilseed processing co-operatives and enable a knowledgeable modification to suit Indian conditions' [NCDC 1980]. USAID 'Food for Peace' donated vegetable oil from US soya bean surpluses will be sold in order to raise funds to cover the foreign exchange requirements for advisors and overseas training for personnel.

The question of the relevance of American management theory to the Indian public sector is not very thoroughly examined, nor is its feasibility in the realities of the Indian political economy. It seems to be taken for granted that oil extraction and emphasizing 'quality control' (specifically by the improvement of laboratory support to the procesing units) are the key

"There is a certain ambiguity about the use of the word 'efficiency' in relation to oilseed crushing because the question of wastage of oil left in oilcake is also a case of viewpoint. To the All India Oilseed Crushing Inquiry of 1955 it was "a loss of the vegetable oil resources of the country', to the management of the NCDC assisted groundnut processing complex at Fatshnagar in Udaipur district of Rajesthan it was a bottleneck to the oilcake supply available for feeding their solvent plant; to the livelihood of thousands of emaciated bullocks, and hence to their owners also, as already discussed, it is very far from 'a waste'. 
problems to be addressed. Most important is the fact that the fundamental question of the need or appropriateness of integrated plants or indeed of solvent extraction techniques to the Indian situation is nowhere touched upon. What is clearly stated is the need for the US soyabean industry to find new markets: 'We know that the pace of growth in oilseed markets set during the last decade won't be sustained to the end of the century without sizeable growth in the earning power of the developing nations' | McQueen, NCDC, 1980]. In other words, it appears that we are discussing a case of an imported technology that is 'inappropriate' because it developed in response to a different economic environment, and 'inappropriate' because it provides a technological solution to the wrong problems.

The irony of the state's contradictory policies towards the oilseed processing industry is this: the fact that chekkus survive at all in the face of competing technologies, is attributable to the very low shadow price or real cost to the economy of labour in rural areas. The state is in effect demobilising its most abundant and therefore valuable resource. The net effect of government policy negates fundamental objectives of Indian Development Plans. Clearly therefore, other criteria have in this case determined government technology choice. In recognition of the need for more research on appropriate policies and feasible technologies we may reiterate one incident of apparent significance: the interest of the US soyabean industry via the medium of CLUSA in its support of the wholesale import of American technical solutions to American marketing problems for soyabean. The World Bank was responsible for financing the survey of rice and oil mills in Tamil Nadu, in 1978-79 [SPIC 1979]. Chekkus were omitted entirely from the enumeration and recommendations related there to the 'need' for solvent extraction plants. The opportunities offered by such institutions clearly help to shape the choices made by those wishing to gain or maintain political power, when rising demand for oilseeds and rising expenditure on imports manifests itself in pressure for rapid and 'visible' action.

\section{Conclusion}

This paper has revealed the utopian nature of policy statements on agro-processing in India. Policy is in fact traced out in acts of resource allocation. The compartmentalisation of such acts, the multiplication of parastatal institutions (at central government and state government levels) in order that such decisions and acts can be compartmentalised, the expansion of the state in some way to regulate an increasing number of markets creates the very conditions for the failure of 'modern' agro-processing technology. This is because inter alia such technologies are vulnerable to changes in 'policy', and the food system is characterised by vacillating and short term 'policies'. The failure can then be attributed to countervailing forces outside the implementing institution and, thus legitimated, the technological and economic failure can be subsidised, as long as the Indian tax base can bear the expansion of this process.

It is clear who loses from such developments. The beneficiaries are a small number of educated employees of the bureaucracy; machinery manufacturers and contractors; the merchant-industrialists who control profitable and efficient technology (on whose private profitability the state ultimately depends for revenue) and international advisors. We shall conclude with the hypothesis that it is the degree of penetration of these experts in the state institutions that shapes priorities in servicing the queue of demands for resources from institutions within India; and, in so doing, shapes food policy.

\section{References}

Achaya, K. T., 1979, 'Appropriate technology for the production and processing of oils and fats industry in India', in UNIDO Monographs on Appropriate Industrial Technology, no 9, UN, New York

Bombay, 1950, Report of the committee for the protection of the village oil industry in Bombay province, Bombay

de Padua, D. B., 1974, 'Post-harvest protection and processing of rice' in McIntyre, R. (ed) Interaction of Agriculture with Food Science, International Development Centre, Singapore

Desai, D. K., 1969, 'Economic implications of modernisation in the paddy rice system' in Indian Institute of Management, Modernisation in Rice Industry, IIM, Ahmedabad

Farmer, B. H. (ed) 1977, Green Revolution?, Macmillan, London

Faulkner, M. D., G. W. Reed and D. D. Brown, 1963, 'Report to the Government of India on increasing outturns of rice from paddy in India', Intensive Agricultural District Programme, Ford Foundation, New Delhi, mimeo

Government of India, 1942, 'Report on the marketing of groundnuts in India and Burma', Marketing Series, no 35 , New Delhi

-1950, The First Five Year Plan, 1950/51 to 1955/56, New Delhi

-1953, 'Report on the marketing of groundnuts in India', Marketing Series, no 73 New Delhi

-1959 , Report on the food crisis and steps to meet it, Ministry of Food and Agriculture, Co-operation and Community Development, New Delhi

-1965, Annual Report. Ministry of Food, Agriculture, Cooperation and Community Development, New Delhi

- 1981, Sixth Five Year Plan, Planning Commission, New Delhi 
Greeley, M., 1978, 'Appropriate rural technology: India's recent experience', Food Policy, vol 3 no 1

Harriss, B., 1976, 'Paddy processing in India and Sri Lanka', Tropical Science, vol 18 no 3, 161-86

-1977 , 'Paddy milling: problems in policy and the choice of technology in B. H. Farmer (ed) op cit

-1979 a 'Post-harvest rice processing systems in rural Bangladesh: technology, economics and employment', The Bangladesh Journal of Agricultural Economics, vol 2 no 1

-1979b, Paddy and Rice Marketing in Northern Tamil Nadu, Sangam Publishers, Madras

- 1981, State and Market, a report to ESCOR of the Overseas Development Administration of the UK Government on state intervention in exchange in a dry region of $S$ India, ODI, London

Indian Institute of Management, 1969, Modernisation in Rice Industry, IIM, Ahmedabad

Jalan, B., 1978, Production in tiny, small and large scale sectors', Economic and Political Weekly, 20 May, vol 13 no 280, p. 852

Kelly,C., 1981, Oilseeds processing technologies in S India and the state's role in technological choice', unpublished MA Thesis, School of Development Studies, Norwich.

Lele, U. J., 1970, Modernisation of the rice industry: lessons from past performance', Economic and Political Weekly, Dept of Agricultural Economics, Cornell University Reprint, Ithaca, NY

-1971, Foodgrain Marketing in India. Public Policy and Private Performance, Cornell University Press, Ithaca and London
National Co-operative Development Corporation, 1975, Chandigarh Seminar Proceedings, New Delhi

-1976, Annual Report 1975-76, New Delhi

-1980, Workshop on co-operative oilseed processing industry - background papers, 28, 29 January

Ngoddy, P. O., 1976, 'Gari mechanisation in Nigeria: the competition between intermediate and modern technology', in Jequier, N. (ed) Appropriate Technology: Problems and Promises, OECD Development Centre, Paris

Panditrao, Y. A., 1980, 'Financing of cottage and village industries', Commerce Pamphlet, no 156, Commerce Publications Division, Bombay

Rao, R. B., 1979, Small Industries and the Developing Economy in India, Concept Publishing Company, New Delhi, 1979

Simmons, E. B., 1975, 'The small scale rural food processing industry in Northern Nigeria', Food Research Institute Studies, Stamford 14, 2, 147-62

Southern Petrochemicals Industries Corporation Ltd (SPIC), 1979, Survey of Rice and Oil Mill Industries in Tamil Nadu, Spic Management Services Group, Madras

Subrahmanyam, V., 1975, 'Recent advances in rice processing, milling and by product utilisation', in NCDC: All India Conference on Co-operative Rice Mill Industry, New Delhi

Timmer, C. P., 1974, Choice of Technique in Rice Milling in Java, Agricultural Development Council Reprint, New York

Wimberley, J., 1969, Evaluation of Modern Rice Milling Program in India, Ford Foundation, New Delhi

\section{Books Received}

Louis Lefeber and Liisa North, Democracy and Development in Latin America, Cerlac-Larn studies on the political economy, society and culture of Latin America and the Caribbean, vol 1, CERLAC, Downsview, Ontario, 1980

John J. Macdonald, The Theory and Practice of Integrated Rural Development, Manchester Monograph 19, University of Manchester, 1982

Peter Maunder (ed), Case Studies in Development Economics, Heinemann, 1982

-(ed), Case Studies in Public Sector Economics, Heinemann, 1982

Health Links, Third World First, Oxford, 1982

Gabriel Carron and Ta Ngoc Châu (eds), Regional Disparities in Educational Development: a controversial issue, UNESCO, Paris, 1980

- Regional Disparities in Educational Development: diagnosis and policies for reduction, UNESCO, Paris, 1980

G. W. Jones and H. V. Richter (eds), Population Mobility and Development: South-east Asia and the Pacific, Development Studies Centre Monograph no 27, Australian National University Press, 1981
Armaments or Disarmament? SIPRI brochure, Stockholm International Peace Research Institute, 1981

Anthony Kirk-Greene and Douglas Rimmer, Nigeria since 1970: a Political and Economic Outline, Hodder \& Stoughton, 1981

Migration and Resettlement: Rural-Urban Policies, vol II Selected Asian Countries; vol III Thailand Country Study; vol IV India Country Study; vol V Philippines Country Study; vol VI Selected Asian Countries: an Overview; vol VII Policy Guidelines: Selected Asian Countries; UNDP/SWDCAP, Manila, 1980

Robert Carty and Virginia Smith, Perpetuating Poverty: the Political Economy of Canadian Foreign Aid, Between the Lines, Toronto, 1981

Romero: Martyr for Liberation, CIIR, London, 1982

Margaret Peil with Peter K. Mitchell and Douglas Rimmer, Social Science Research Methods: an African Handbook, Hodder \& Stoughton, 1982

George Beckford and Michael Witter, Small Garden . . Bitter Weed: Struggle and Change in Jamaica, Zed Press, London, 1982 